\title{
FREE TRADE, POLITICAL ECONOMY AND THE BIRTH OF A NEW ECONOMIC NATION: BRAZIL, 1808-1810*
}

JOSÉ LUÍS CARDOSO

Instituto de Ciências Sociais, Universidade de Lisboa ${ }^{a}$

\begin{abstract}
In late 1807, Brazil was still a part of the Portuguese empire. As a consequence of the outbreak of the Peninsular War, the Prince Regent and the court moved to Brazil, an amazing voyage planned as a way of safeguarding Portugal's sovereignty over her vast territories. When the royal ships arrived in Brazil, the first measure to be taken was the decree which opened up Brazilian ports to British commercial vessels, thus putting an end to the old system of exclusive colonial trading between Brazil and Portugal. This was indeed the very first sign of a much larger process of economic liberalisation that was shortly to follow. In this process, a special role was to be played by the science of political economy used as a rationale for economic change and ultimately serving as an instrument for political independence.
\end{abstract}

Keywords: free trade, political economy, economic liberalism, Napoleonic wars, Brazil

JEL Classification: B10, N46

* Received 04/29/2008. Accepted 03/17/2009. A preliminary version of this article was presented at the Annual Conference of the European Society for the History of Economic Thought, Prague, May 2008. The author is grateful to the comments provided by Bertram Schefold, Pedro Lains and two anonymous referees of this journal. The usual disclaimer applies.

a Instituto de Ciências Sociais. Universidade de Lisboa. Av. Professor Aníbal de Bettencourt, 9, 1600-189 Lisboa, Portugal. jcardoso@ics.ul.pt. 


\section{RESUMEN}

Al final de 1807, Brasil era la joya del imperio portugués. Ante la amenaza de invasión del territorio por parte del ejército napoleónico, y con el objetivo de garantizar el pleno ejercicio de la soberanía política, la corte portuguesa se trasladó a Brasil. La primera acción del Príncipe Regente Don Juan fue decretar la apertura de los puertos brasileños al comercio de las naciones amigas, poniendo fin a un largo periodo de comercio exclusivo colonial entre Brasil y la metrópoli. Gran Bretaña fue la principal beneficiaria de la apertura del comercio brasileño, así como de otras medidas de liberalización económica inspiradas en los principios y doctrinas de la economía política. De esta forma, esta ciencia asumió un papel decisivo en la cimentación de la autonomía económica de la nación brasileña, lo que vendría a afianzar su independencia política en 1822.

Palabras clave: librecambio, economía política, liberalismo económico, guerras napoleónicas, Brasil

\section{INTRODUCTION}

The purpose of this article is to demonstrate the relevance of economic ideas for a better understanding of the process of change that occurred in the Portuguese colonial empire in the first decade of the nineteenth century. The analysis is focused on the work and action of two important interpreters of Portuguese and Brazilian economic thought of that period, namely: Rodrigo de Souza Coutinho and José da Silva Lisboa. The former was an important minister in the government of Prince Regent Dom João in two different periods, between 1796 and 1803 and between 1807 and $1812^{1}$; he was an enlightened reformer who made extensive use of economic knowledge as a rationale for economic policy decisions ${ }^{2}$. The latter was a public servant who held important posts in the political and economic administration of Brazil, as well as the author of several pamphlets and books which popularized the science of political economy.

The study of the relevance and impact of ideas calls for the analysis of the way they relate to the real world which is to be comprehended and, eventually, transformed. Ideas are neither immune to nor separate from their practical consequences, as they also adapt themselves to the perceived and

${ }^{1}$ Prince Regent Dom João had reigned in Portugal since 1792, due to the mental illness of his mother, Queen Maria I. He only became King Dom João VI in 1816.

${ }^{2}$ Before entering the government, Coutinho served for seventeen years in Turin, Piemonte, as the Ambassador of Portugal in the court of Sardinia. For a detailed and thorough biography of Souza Coutinho see Silva (2002-2006). 
changing reality. Therefore, it is also the aim of this article to show the effects that the ideas and actions undertaken by both Rodrigo de Souza Coutinho and José da Silva Lisboa had on the development of the Brazilian economy and the design of its new institutional setting.

Souza Coutinho and Silva Lisboa lived in a period of disintegration of the traditional colonial pact that tied Brazil to the European metropolis, Portugal. The context of the Napoleonic wars in Europe forced the Portuguese crown to move to Brazil and this was much more than a mere transfer of the empire's capital. Indeed, this move would represent a great opportunity for an autonomous development of Brazilian economy and society. Authors of that period who were learned in political economy have shown that the changes under way could be explained with the help of economic principles and doctrines, and this is precisely the main topic to be addressed in the present article. Sections 2 and 3 discuss the orientations in colonial policy put forward by Rodrigo Souza Coutinho, with a special emphasis given to the economic changes motivated by the broader diplomatic and political international context. Section 4 presents the main arguments offered by José da Silva Lisboa in his attempt to defend the opening of the Brazilian economy in the light of the sound principles of political economy. Section 5 concludes.

\section{GUIDELINES FOR AN ENLIGHTENED COLONIAL POLICY IN BRAZIL (1796-1801)}

The great commercial prosperity enjoyed by the Portuguese empire towards the end of the eighteenth century was largely due to the role played by Brazil, not only as a provider of raw materials and foodstuffs, for which there was a growing demand in European markets (particularly sugar and cotton) and thus as a source of intense re-export trade, but also as a consumer of products manufactured in the metropolis, as well as wine and slave labour from the African colonies ${ }^{3}$. Therefore, it was only natural that the enlightened minister Rodrigo de Souza Coutinho should always keep a close watch on the political and economic administration of Brazil, aware of the crucial importance that the Brazilian economy and colonial trade had for the maintenance of economic equilibrium within the realm as a whole.

His vision was by and large inspired in the traditional mercantilist approach to the role of colonies within European empires. According to the view defended by the mercantilist literature, the colonies guaranteed the

${ }^{3}$ This topic has deserved a thorough analysis in both Brazilian and Portuguese historiography. To follow the main arguments and historical description, see Novais (1979), Arruda (1980), Alexandre (1993) and Pedreira (1994). For a summary presentation see Pedreira (1998) and Schwartz (1998). 
supply of raw materials and consumer goods both for direct use in the European continent and for later re-export. They similarly functioned as a protected market for selling the products manufactured in the metropolises, whilst further ensuring that the balance of trade remained favourable and guaranteeing the continued accumulation of precious metals. They also served as destinations for voluntary or enforced emigration and sources of tax revenue. The systems of exclusive contracts and monopolies, as well as the financial and fiscal privileges inherent therein, provided a firm guarantee of success for the different economic agents involved in colonial trading operations, beginning with the State itself. Consequently, the survival of this colonial system of the mercantilist type was guaranteed through a series of security mechanisms and through military protection, as well as through regulatory measures that guarded against the occurrence of any possible conflicts of interest. All these features were present in the colonial relationship between Portugal and the jewel of its crown, Brazil.

Despite the tacit acceptance of the advantages arising from the «colonial pact» system briefly described above, it is nevertheless apparent that Souza Coutinho was also receptive to a new way of looking at the role of the colonies, implying the revision of a more conventional attitude concerning the formation of empires, namely as regards the possibility to foster a certain degree of economic autonomy in the colonies. This enlightened outlook is clearly shown in the writings of several mid-eighteenth century authors such as Josiah Tucker, Mercier de la Rivière, Turgot and the Abbé Raynal, among others. Above all, however, it was Adam Smith who organised and gave added strength to a series of critical reflections on the nature of colonial trade and the need for its reform (Smith, 1776, pp. iv-vii). Smith also clearly expressed the existence of disturbing doubts regarding the possibility of maintaining the empires and their real or illusory wealth.

After Smith, the theme of the colonies became the central issue in a number of interesting debates that took place in the history of economic thought. Weighing up the economic advantages or disadvantages brought by colonies to their respective metropolises, comparing viewpoints on the most suitable ways of managing or promoting their development, or even discussing the financial and administrative implications connected with the existence of empires, were just some of the recurrent themes in these debates ${ }^{4}$.

Having been one of the first Portuguese readers of the Wealth of Nations, Souza Coutinho was certainly aware of Smithian teachings when he took over his position as Minister of the Navy and Ultramarine Domains in late 1796. He presented a straightforward programme of reforms to be implemented in the colonial system and advocated a global vision of the empire based on two main principles: political unity and economic interdependence.

${ }^{4}$ For a general discussion of the colonial question in Smithian and enlightened political economy see Braun (1989), Semmel (1970), Stevens (1975), Winch (1965) and Winch (1996). 
The principle of political unity was expressed in the idea that the overseas dominions of America, Africa and Asia were "provinces of the monarchy», and therefore integral parts of a whole whose centre was in Europe. In other words, «His Majesty's dominions in Europe are no less than the capital and centre of his vast possessions» (Coutinho, 1797, p. 48). Whilst keeping this principle in mind, he sought both to avert and prevent the risk of political independence movements, such as those that had already begun to appear or threatened to break out in other European dominions in America. These would, however, have difficulty in spreading to the Portuguese empire, since «this bond between the Portuguese overseas dominions and their metropolis is as natural, as it has been unnatural in other colonies separated from their motherland» (ibid., p. 48).

The principle of economic interdependence, on the other hand, involved pointing out the rules governing the relationship between the different overseas dominions and the metropolis, discouraging the establishment of direct economic relations between the parties without the intervention and control of the metropolitan centre. Indeed, his thoughts on this matter are perfectly clear when emphasising that interdependence could not be conceived without the supremacy and control of the centre: «The relations of each dominion must, for their mutual advantage, be more active and more intense with the metropolis than amongst themselves, for only in this way will union and prosperity achieve their greatest heights» (ibid., p. 49).

The principles and guidelines set out by the minister Souza Coutinho were in keeping with his basic concern of providing Brazil with a modernised economic and financial structure adapted to the needs of the whole empire ${ }^{5}$. However, the achievement of such an aim also called for the adoption of a number of measures which would endanger some of the basic prerogatives of a colonial regime of the mercantilist type. Such was the case with the proposals for the abolition of the salt contract and for the reduction or removal of the import duties on metropolitan products at Brazilian ports. The instructions given to the governors of the provinces in Brazil also included identical proposals for the abolition of the privileges created by exclusive contracts, with the basic argument that this would be one of the main ways of increasing the crown's tax revenue ${ }^{6}$. It is precisely regarding these issues that Souza Coutinho's actions reveal his enlightened inheritance of Smith's system of political economy.

\footnotetext{
5 Similar attempts were made in Bourbon Spain and its American empire in the same period. For an integrated approach of the new conceptualization of the Spanish monarchy and its relation with a changing colonial economy and a reformed institutional setting, see Paquette (2008). This book also offers further clarification of the role played by the discourse of political economy to consolidate the reform programme.

${ }^{6}$ The contents of this unpublished correspondence with the governors - which is kept in the National Archives of Rio de Janeiro- as well as the meaning of the economic reforms put forward by Souza Coutinho, are discussed in Cardoso (2001).
} 
Another aim of these measures for the liberalisation of the colonial market was to stimulate the activity of traders, who were prevented from operating freely in a market with so many restrictions of a monopolistic nature. The idea was also to provide an incentive for agricultural and manufacturing production in continental Portugal which would benefit from the increased demand in the Brazilian market.

This support for the opening up of the colonial economic organisation should not, however, be interpreted as an unreserved acceptance of the principles of laissez faire, nor as an unconditional defence of the supremacy of individual self-interest.

In some cases, the policy of improvements could be accompanied by a certain opening up of colonial economic life ${ }^{7}$. Political economy of the Smithian kind was a useful tool for legitimising these reformist aims, but there was still a certain distance and reserve in the declarations he made regarding the universal validity of Smith's theories. It was not until 1808, when the international situation had become particularly delicate and attractive, that the doctrinal discourse of Souza Coutinho turned out to be more receptive to the ideas of economic liberalism.

\section{A NEW CONTEXT FOR NEW ECONOMIC POLICIES (1808-1810)}

The mission undertaken by Rodrigo de Souza Coutinho at the head of the Ministry of the Navy and Ultramarine Domains was extremely fruitful, his skills and competences as a political reformer being fully acknowledged. The period during which he was minister, between 1796 and 1801, provides full evidence of an increase of both exports of Portuguese manufactured goods to Brazil and re-exports of Brazilian products in European markets, thus closing a cycle of sustainable growth of colonial trade initiated in the early $1770 \mathrm{~s}^{8}$. A special reference is due here to the careful attention he paid to the implementation of improved knowledge of Brazil's natural resources, through the promotion of scientific expeditions and "philosophical voyages», explicitly designed as a means of obtaining gains and efficiency in the economic allocation and use of those resources. This endeavour clearly shows the role that Coutinho assigned to science as an instrument of economic development.

The political experience he gained during this first phase of participation in government paved the way for the outstanding position as President of the

\footnotetext{
${ }^{7}$ For a summary presentation of the enlightened reforms implemented in colonial Brazil in the late eighteenth century see Maxwell (1973) and Maxwell (1998).

${ }_{8}$ The lack of data for the Portuguese balance of trade prior to 1796 does not allow for the quantification of the evolutionary trends of foreign trade during the last decades of the eighteenth century, nor for the analysis of the share of Brazilian trade. The most rigorous attempt to survey the patchy available data was made by Pedreira (1994, chap. V). For a summary presentation in English of the main conclusions of this study see Pedreira (2000).
} 
Real Erário (Royal Exchequer) from 1801 to 1803. Coutinho was appointed with the task of controlling the difficult financial situation that Portugal was experiencing. The financial troubles stemmed from a variety of circumstances, notably the increase of military expenditure derived from the participation of the Portuguese army in the campaigns of Roussillon and Catalonia (17931794) against the French attempts to gain control over the Iberian countries. The deficient functioning of the taxation structure, as well as the need to guarantee the credibility of the fragile public debt system and to control the circulation of paper money were other reasons that called for the careful attention of Souza Coutinho. He took this occasion to substantiate his knowledge and capacities concerning the management of the public finance system. Despite the fact that the main priority was public finance management, Souza Coutinho was still able to put forward an enlightened programme of reforms for implementation in various sectors of economic activity. He particularly focused on the need for a total modernization of the agriculture sector, which required both a considerable increase in capital flows and a huge reduction of the constraints on the extension of the domestic market.

However, his merits as an educated statesman and reformer were not sufficient to overcome the increasing diplomatic tensions continuously threatening his political reputation. At a time when there was an apparent divide between French and English partisans, Sousa Coutinho wholeheartedly chose the English side and therefore voluntarily stepped out of the government at the end of 1803. This was a clear sign of victory of the French diplomacy and Souza Coutinho would remain far from the circle of counsellors of the Prince Regent Dom João for almost four years. In mid-1807, when it was made obvious that the neutrality desired by the Portuguese was no longer possible when Napoleon forced Portugal to accept the conditions of the Continental Blockade fully, Souza Coutinho was called on once again to become a member of the Council of State and, in this capacity, he drew up the plan for firm resistance to Napoleon's intentions. The French threat turned into a real invasion in late November 1807, therefore forcing the Portuguese crown to move to Brazil, hence aborting Napoleon's attempt to withdraw Portugal from the political map of Europe.

Souza Coutinho emerged on this occasion as the main mentor and adviser of the Prince Regent, shortly to become King Dom João VI. In his eyes, the move to Brazil did not represent a flight taken in fear ${ }^{9}$. On the contrary, it was simply the implementation of a plan perfectly in keeping with the idea of an imperial nation, whose seat of power could be moved temporarily, if this was considered necessary, in order to maintain its integrity. Eleven years

9 This important episode of the displacement of Portuguese court to Brazil in the context of the Napoleonic wars has received detailed attention from historians in both sides of the Atlantic. For an overall discussion of the process of institutional and political change associated to the move of the court see Schultz (2001). 
after writing his Memoir in 1797, Rodrigo de Souza Coutinho seems to have remained faithful to the principle of ensuring the political unity of the Empire, a principle which helped to consolidate the national feeling of repulsion at the threat, and indeed the temporary success, of the French occupation of continental Portugal.

In relation to the other principle considered essential for sustaining the imperial monarchy, i.e. the economic interdependence of the colonies under the rule of the European metropolis, the evolution of the political and diplomatic situation was to impose significant changes on the prevailing model. A European-centred colonial policy, which restricted and subordinated the supply and development of the overseas dominions to the economic imperatives of the continent, had ceased to make sense. This was because the most important consideration now was that these dominions should become the permanent residence of the king and his court. It also ceased to be unthinkable that the undertakings arising from the alliance with England, which was now under siege from the rest of Europe, should not be immediately fulfilled, for this latter country was seriously in need of the raw materials and markets that could be provided by the Portuguese colonies. The valuable and decisive military aid that the British sent to free continental Portugal from Napoleon's invading forces came at a price that could not be haggled over.

The first sign that the colonial market had been opened up to the British was given immediately, even before the court had landed at Rio de Janeiro. On 28 January 1808, a Carta Régia (Royal Charter) was issued from Bahia ordering that «all and every kind of commodities, wares and merchandise transported either in foreign vessels belonging to the powers that remain at peace with my royal crown or in ships belonging to my vassals are to be admitted by the customs of Brazil». The duties fixed were 24 per cent ad valorem, and the Charter made it clear that «not only my vassals, but also the aforesaid foreigners may export to these ports, whenever it seems to them to be of benefit to trade and agriculture, which I so much wish to promote, all and every kind of commodities and colonial products, apart from Brazilwood and other manifestly monopolised commodities» (CLP, vol. V: 477) ${ }^{10}$.

Until then, the possibility of acts of a commercial nature being undertaken in Brazilian ports had only been allowed in exceptional situations of enforced docking, in which, due to a lack of sufficient means for payment, the expenses had to be defrayed through the sale of the goods that such vessels were transporting. The opening up of the ports now being decreed was the first sign of the much greater economic liberalisation shortly to follow ${ }^{11}$.

10 The collection of laws and decrees, hereby quoted as CLP, is also available as Colecção das Leis do Império do Brasil, and may be searched by date at: http://www2.camara.gov.br/legislacao/publicacoes/doimperio.

11 For an updated discussion of the relevance of this process of the opening of the Brazilian ports, see the collection of essays included in Oliveira and Ricupero (2007). 
The second legislative measure decreed by the Prince Regent was also announced in Bahia: the setting up of a course in political economy, intended to provide the enlightenment of good governance (Decree of 23 February $1808, C L P$, vol. V, p. 478). Such a measure was certainly well received by a group of Brazilian intellectuals, who were particularly sensitive to the importance of erudite learning and practical knowledge for the modernisation of the colony's economic and social life. The political impact and symbolic significance of this fact could not have been any greater. In an age when such profound changes were taking place in colonial relations and an economic space was being created that would be suitable for experimenting with and testing economic liberalisation measures, there was nothing better than to seek to formally institute learning and encourage the spread of the principles that were to guide the activity of the new political administration now based in Brazil. And, as we shall see, the good news announced by the science of political economy was to leave a distinct impression.

Meanwhile, the legislation published continued to underline just how profound these changes were. The decree of 1 April 1808 revoked the earlier ban on the installation of manufacturing processes in Brazil and overseas dominions and authorised «any of my vassals to establish all kinds of manufacture, without any exception whatsoever, carrying out their work on a small or a large scale, as they see fit» (CLP, vol. V, p. 484). The decree of 28 April 1809 exempted «all raw materials that are used as the basis of any manufacture» from the payment of customs duties, whilst the products made from these materials would also be exempt from duties. Furthermore, the same decree created incentives for the eintroduction of new, costly and extremely useful machinery», in order to fully equip the industrial structure that was emerging in Brazil (CLP, vol. V, p. 733) ${ }^{12}$.

The main consequence of this opening up process was a considerable increase in the trade operated by British ships and British merchants and, in general terms, a significant weakening of Portuguese trade with Brazil. In fact, in the period 1808-1813 exports and re-exports from Portugal to Brazil declined to 15.9 per cent of the value reached in 1796-1806 (annual average, at constant prices), while imports from Brazil and re-exports of Brazilian products fell to 19.8 per cent and 11.6 per cent respectively of the value reached in the period 1796-1806 (Pedreira, 1994, p. 325).

This slowdown was surely amplified by the collapse of the Portuguese industrial structure, stemming from the war devastations caused by the invading French army. Nevertheless, the ultimate reasons for the disaster are to be found in the structural weaknesses and shortcomings of the Portuguese productive system which was not adequately prepared to face the competitiveness of British manufactured products. It also lacked capital investment,

${ }^{12}$ See also the decrees of 6 October 1810 and 13 July 1811, which have very similar contents (CLP, vol. V: p. 917 and vol. VI: p. 58). 
a qualified workforce and a culture of entrepreneurship, as well as being extremely dependent on state protection and control. Consequently, the opening of Brazilian ports was a crucial moment which explains the intensification of a process of collapse which, however, had already become apparent in the balance of trade data from 1799 onwards (Lains, 1989, p. 96) ${ }^{13}$.

The transfer of the court to Rio de Janeiro and the settlement of circa 15,000 new inhabitants moving from Portugal throughout the first semester of 1808 brought about a considerable increase in the demand for consumption goods. British merchants and manufacturers did not annihilate the chances offered for profitable operations in Brazil. As a mere illustrative note, one should bear in mind that in the year 1808 the number of foreign ships entering the port of Rio de Janeiro was 90; the number quickly rose to 422 two years later, of which most were British ships (Manchester, 1933, p. 76).

The number of British commercial firms and departments in Rio de Janeiro also increased considerably. In August 1808 there were 150 new merchant houses, representing almost 30 per cent of the total of Portuguese and foreign trade establishments existing in the city (ibid., p. 76). The British share is still greater if we take into account the number of illegal agents desperately trying to obtain easy riches in the tropics.

It must not, however, be forgotten that the above-mentioned legal facilities granted for the installation of manufactures in Brazil could also pose a threat to the British predominance over their competitors, which had initially been guaranteed by the opening up of the ports. If any doubts remained, an analysis of the contents of the Treaties of Commerce and Friendship signed between Portugal and Great Britain in February 1810 would soon cause them to vanish. In fact, these treaties introduced a clear imbalance into the much-vaunted freedom of production and trade now legislated for, an imbalance that meant that the clauses and prerogatives tipped the scales in favour of the British. British manufactures obtained preferential conditions through a reduction in import duties, which made Portuguese products even less competitive ${ }^{14}$. The tariffs on British goods transported by British or

${ }^{13}$ The assessment of the immediate and long-termconsequences of the collapse of Brazilian trade is still a source of controversy and dispute among Portuguese economic historians. According to Valentim Alexandre, the moment remains as a key factor explaining the process of underdevelopment of the Portuguese economy throughout the nineteenth century (Alexandre 1986 and Alexandre 1991). Pedro Lains considers that the fall in exports of Portuguese manufactured goods to Brazil would be irrelevant and the losses from 1808 onwards would be equivalent to a maximum of 2.4 per cent of the GNP value of 1830 (Lains 1991). Jorge Pedreira made a correction to this guessed projection in retrospect, suggesting that the amount of losses of Brazilian trade would amount to a maximum equivalent to 8 per cent of the GNP value of 1827 (Pedreira, 1994, p. 365). For a good summary of the main arguments in dispute, as well as of the creativity allowed by incomplete economic series, see Pedreira (1994, pp. 359-375) and Madureira (1997, pp. 334-340).

${ }^{14}$ For a summary presentation of the nature and historical meaning of the 1810 treaties cf. Pereira (1987), Pedreira (1998) and Neves (1995). 
Portuguese ships were 15 per cent ad valorem, while the tariffs on Portuguese or foreign goods transported by Portuguese ships were 16 per cent ad valorem, and on other foreign goods carried on foreign ships the figure was 24 per cent ad valorem.

The development of national structures for industrial production - particularly the attempts to establish manufactures in Brazil- could not be planned independently of the terms implied by a political alliance essential for maintaining Portuguese political sovereignty intact. The 1810 treaties therefore demonstrated the ambivalence of a destiny that, in order to become fact, also had to be negotiated under adverse economic conditions. A summary picture of the new situation may be presented in the following terms: from 1796 to 1810, Brazil represented a share of 54 per cent of the average annual value of Portugal's international trade (imports, exports and reexports); between 1811 and 1820 the share fell to 33 per cent. In the same 1796-1810 period the weight of Great Britain in Brazilian trade represented 23 per cent, while over the period 1811-1820 it increased to 37 per cent (Caetano, 2008, p. 38). This shift also meant that, by losing its previous colonial status, Brazil became gradually and inevitably tied to the British Empire ${ }^{15}$.

Let us now return to Rodrigo de Souza Coutinho, who played a leading role throughout this process. In the new government established in Rio de Janeiro, Souza Coutinho, then given the title of Count of Linhares, was formally in charge of the Ministry of War and Foreign Office. However, his functions had largely taken over the activities of the other members of the government. As the leading counsellor of the establishment of the court in Brazil, he was effectively in charge of all political affairs until his death in early 1812. The re-shaping of political and legal institutions and their adaptation to the needs of a court displaced from its natural, European setting was, on the whole, the outcome of his political leadership. Similarly, the design of new economic and financial institutions, namely the Real Erário (Exchequer) and the Junta do Comércio, Agricultura, Fábricas e Navegação (Board of Trade, Agriculture, Manufactures and Navigation), benefited greatly from his experience and expertise in these areas of government in continental Portugal in the early 1800s. In this particular field, his responsibility for the creation of the Bank of Brazil in October 1808 should be emphasised, as it corresponds to an integrated vision of the role of financial institutions, both private and public, working together with the aim of promoting economic development. Another set of measures of institutional design and adaptation which depended on the personal commitment of Souza Coutinho was the creation of the Jardim Botânico (Botanical Gardens) and the esta-

15 On this topic of the British pre-eminence in Brazil, the classical and thorough study by Manchester 1933 is still worth reading. On the uprising of British interests see also Freitas (1958) and, more recently, Arruda (2008). 
blishment of the Impressão Régia (Royal Print) and other educational structures conceived to promote the formation and spread of knowledge.

As for the main subject addressed in the present article, it is worth underlining that the decrees which provided incentives for manufacturing production in Brazil were certainly the work of Rodrigo de Souza Coutinho. He was also responsible, on behalf of Portugal, for negotiating and signing the Tratado de Comércio of 1810, which introduced the commercial privileges granted to British manufactures.

The justification of the new economic and social equilibriums arising from the treaty was publicly defended in the Carta Régia of 7 March 1810, whose wording was also the work of Rodrigo de Souza Coutinho, the Count of Linhares. This is a highly significant document for two fundamental reasons: firstly, because it summarises and justifies the measures and undertakings established by the Portuguese court in Rio de Janeiro; secondly, because it seeks to minimise the effects of the treaty between the British and the Portuguese, announcing a series of measures that would guarantee the economic development of the realm, especially in regard to its continental component. In both cases, the explanatory arguments resorted to the language of political economy.

As a justification of the reforms introduced in Brazil, and as a result of the court's transfer to Rio de Janeiro, the Carta Régia stated that it had been «necessary to seek to build those parts of the empire free of oppression» and that, for this purpose, it had been necessary to «adopt the most clearly demonstrated principles of sound political economy, such as freedom, free trade and the reduction of customs duties, in keeping with the most liberal principles» (CLP, vol. V, p. 859). The overall aim behind the liberalisation of the Brazilian economy was naturally to ensure an increase in the supply of agricultural and manufactured products to match the increased demand.

This was the explanation for the lifting of the ban on the setting up of factories in Brazil and the fostering of a system of free production and trade whose legitimacy was supervised from above for reasons of «sound political economy». It also explained why, to prevent it being thought that the development of the realm's manufactures would consequently be neglected, the Carta Régia referred to the measures taken to exempt the products manufactured in the metropolis from payment of import duties at Brazilian ports ${ }^{16}$. For Souza Coutinho, who was a perceptive reader of Adam Smith, there was absolutely no doubt as to the advantages inherent in the modification of the old colonial system, particularly in view of the added possibilities for development provided by an open economy, as can be seen from the following words:

${ }^{16}$ Decrees of 28 January 1809 and 7 August 1810 (CLP, vol. V: pp. 723 and 900). 
«Portugal will gain more from the increase that Brazil will have after the liberal principles that Your Royal Highness has ordered to be established there than it earned previously with the restricted colonial system that used to exist; Portugal will always be the natural repository for foodstuffs from Brazil, and the repository will be much larger; Portugal will provide a better and greater consumption of its products and manufactures than it did previously; and, finally, the example provided by events in England after the separation of the United States, which Smith had predicted, will also happen in Portugal» ${ }^{17}$.

Both in the metropolis and in Brazil, an attempt was being made to put into practice a "great and liberal system of trade», which, for Rodrigo de Souza Coutinho, naturally culminated in the treaty of commerce and friendship signed with Great Britain. It is beyond doubt that all these matters were well received by Brazilian intellectuals, who, in a somewhat pioneering fashion, had argued in favour of the adoption of the doctrinal principles of laissez faire. Amongst this group, pride of place must be given to José da Silva Lisboa, for the militant enthusiasm with which he advocated the opening up of the Brazilian economy in the light of the message conveyed by the Wealth of Nations.

\section{FREE TRADE AND POLITICAL ECONOMY DEFENDED}

After concluding his studies in Law at the University of Coimbra, Silva Lisboa started a career both as a civil servant and as an occasional writer on political and commercial issues ${ }^{18}$. The unexpected success of his book on Commercial Law encouraged him to embark on a more challenging venture - the Principles of Political Economy (1804). This second book was clearly less neutral than the previous one, largely on account of its forthright support of the undisputable superiority of Adam Smith's economic ideas over other existing doctrines.

When the Prince Regent, Dom João, landed in Bahia, in January 1808, José da Silva Lisboa was the Deputy Secretary of the Chamber of Agriculture and Commerce in that city, having held this position since 1798. It is known that, acting in this institutional capacity, he directly intervened in the publication of the Carta Régia of 28 January 1808, which decreed that the Brazilian ports were to be opened up to trade. It is also known that the second measure decreed by Prince Dom João, the creation of a course in political economy to be taught at Rio de Janeiro, was introduced precisely with José da Silva Lisboa in mind, for he was to take responsibility for the tea-

17 Letter to the Prince Regent of 16 August 1809, in Lima (1909, vol. II, p. 214).

18 On the significance of this author's work, cf. Almodovar (1993) and Rocha (1996). 
ching of science, which would help to explain how best to follow the path that led to the common good and public happiness. Though the launching of the chair of political economy did not succeed, Silva Lisboa moved to Rio de Janeiro where he was appointed as a member of the Board of Trade, Agriculture, Manufactures and Navigation, as well as a member of the Supreme Court and as an adviser of the Royal Print. The relevance of his public obligations should be emphasised, as it offers further evidence of the impact of his writings on the constitution of a public sphere in Brazil in that period $^{19}$.

His commitment to defending and explaining the advantages arising from the opening of the Brazilian ports led him to write a lengthy pamphlet entitled Observações sobre o Comércio Franco no Brasil (Some Observations on Free Trade in Brazil, Lisboa, 1808-1809) ${ }^{20}$, which, curiously, was the first book to be published by the royal printers, Impressão Régia, newly set up at that time in Rio de Janeiro.

In the first part of this text, he expounds some general principles in favour of free trade, based on the idea that «Free trade, regulated by moral rectitude and the common good, is the life-giving principle of the social order, and the most natural, and safest means of ensuring the prosperity of nations" (Lisboa, 1808-1809, p. 188). The application of these general principles was inevitable in the context of the transfer of the court to Brazil, for only in this way would the market be kept supplied and in a buoyant state. In the course of the argument put forward, Silva Lisboa demonstrates the mastery he enjoyed of the science of political economy as a discourse organised for interpreting the way in which economic life functioned, as is clearly illustrated by the following excerpt:

«Free trade in Brazil will be of progressive interest to both the crown and nation. The former will have greater revenue, in proportion to the greater quantity of imports and exports, which will pay the established duties; and the latter will continuously increase its resources, awaking from the lethargy into which the country's industries have been plunged, and introducing other manufactures through new directions, which the energy of private interest, left to its natural elasticity and with all barriers removed, must find through the constant emulation and conflict of national and foreign competitors (...). The greater the number of buyers of colonial goods, the greater the extraction and value that these will have; so that their subsequent and increasing reproduction will consequently be encouraged» (ibid., p. 194).

${ }^{19}$ On these aspects of the life and work of José da Silva Lisboa, cf. Cardoso (2002).

${ }^{20}$ All references to this text are from the critical edition included in Lisboa (1993, vol. I, pp. 185$320)$. Another recent critical edition of this text is available in Rocha (2001, pp. 61-210). 
Silva Lisboa's vision closely follows the line of reasoning of Adam Smith's political economy, when, in this passage, he explains the advantages of extending the market in order to increase the productive power of labour and to guarantee the continued accumulation and reproduction of the wealth created. This same source of inspiration provides him with the framework for his positive assessment of the market, not only as a space for the development of the "energy of private interest», but also as a process for accomplishing social virtues based on the idea of reciprocity and the exchange of equivalents, counteracting the spirit of greed and momentary gain, exemplified by the apparent advantage of selling high and buying low. Or, in other words: «The true spirit of trade is a social one: it wants to help and to be helped: it aspires to give succour and to receive it: it requires reciprocal benefit and can only be fertile, and constantly useful, when it is shared» (ibid., p. 195).

In these and other observations, it is possible to note the powerful presence and influence of Adam Smith. In fact, Silva Lisboa does no more than repeat a profession of faith clearly demonstrated in the book he had published four years earlier (Lisboa, 1804). The putative detractors, daring to accuse Adam Smith and his faithful follower of the sin of abstraction, are answered by Silva Lisboa with the explanation that "Smith's doctrine on free trade does not consist of a mere theory dreamed up in his study; it is based on indisputable facts, on the instincts and feelings of all men who are not preoccupied with their own selfish interest, and on the experience and history of nations» (Lisboa, 1808-1809, p. 288).

Regardless of his deep-rooted adherence to liberal economic ideas, Silva Lisboa also refers to a broader notion that was more widely accepted amongst various 18th-century authors who considered the development of international trade as a factor of peace and harmony between nations ${ }^{21}$. It is this enlightened idea of doux commerce, the criticism made of the prejudices of greed and envy between nations, which distinguishes such comments from the superficial appeal to laissez faire, but which also shapes the economic liberalism of authors such as Adam Smith or Silva Lisboa. This is a new vision of economic citizenship based on the profitable possession of property, the refinement of customs and the renunciation of frugality and austerity, accompanied by a new attitude in relation to the civic virtues of the search for individual interest and freedom in the operation of markets ${ }^{22}$.

During the second half of the 17th century and the first half of the 18th century, several authors were to touch upon the theme of human civility as a way of extending self-love and as a pretext for the development of a utilitarian model which anticipated the general lines of the discussion surroun-

\footnotetext{
${ }^{21}$ An exhaustive panorama of this subject is provided in Hont (2005, pp. 1-155).

${ }^{22}$ On the relevance of this topic for the understanding of the liberal stance in political economy discourse, cf. Hirschman (1977).
} 
ding economic individualism to be found in the liberal doctrine. This is a vision of self-love (and individual interest) as a factor influencing the development of the conditions under which the market operates. Doux commerce, as Montesquieu called it, subordinates the idea of illicit business and gives special privilege to the notion of social interdependence inherent in the extension of mercantile relations, understood here as being relations of mutual dependence between individuals who are able to derive benefits from trading what they own or produce in exchange for other goods that they need. In bringing individuals closer together, trade also brings together nations which calmly establish beneficial relations of interdependence, so that peace between nations is a condition, but also a consequence, of the civility that is generated by trade.

In this explanatory context, which, one supposes, may also have been the one that implicitly shaped the thinking of José da Silva Lisboa, the opening up of the ports to trade was not only a way of putting into practice the ideals of laissez faire; it also represented the embodiment of the idea that trade is a factor of peace and harmony between nations.

Returning to the topics that he develops in his Observations on free trade, it is worth pointing out how, in the second part of this text, he expounds and anticipates arguments in reply to those who might seek to find in the opening up of the ports a surrender to British demands. Silva Lisboa considers that no complexes should be felt about recognising the benefits resulting from the fact that Great Britain is Europe's richest and most industrious nation, so that such an advantage should be clearly recorded and, even better, celebrated «out of necessity, interest, politics and national gratitude» (Lisboa, 1808-1809, p. 200).

In the British, he praises the excellence and quality of their manufactured products, the availability and abundance of their capital and their enterprising spirit, their perspicacity in taking advantage of opportunities, the regular administration of justice, the fight against monopolies, the development of science and of the instruments of trade. He therefore considers that the more intense the trading relations with the British, the greater the possibilities for Brazil of participating in and sharing the benefits of these lucrative activities.

Silva Lisboa demonstrates that the «interim and provisional» nature of the Carta Régia which established the opening up of the ports might and, in his opinion, should become more permanent. This is what he seeks to demonstrate in the third and last part of his text, in which he reviews and refutes the objections that might be raised to the pursuit of a coherent free trade policy.

The first of these objections would be the possible exit from Brazil of money and precious metals, taken by foreigners as payment for their merchandise. Silva Lisboa adopts an analytical view identical to J.-B. Say's famous law of markets, stating that: 
"In civilised countries, and mainly in traders and seafarers, the money that is indispensable for performing the functions of a currency can only be missing, when there is stagnation in trade, for powerful and durable reasons. A void is then felt in circulation; not because there is no money, but because it is being hoarded, because it has no useful employment» (ibid., p. 247).

In other words, the problem of a possible stagnation in trade was not to be found in the excess demand for money in relation to the amount available, but rather in the absence of products in sufficient quantities to be traded. The increased demand for imported goods was an inevitable consequence of the establishment of the capital of the kingdom in Rio de Janeiro, given the obvious increase in expenditure on consumer goods and circulating capital.

"What would happen to the State if it [free trade] did not exist in these miserable times? Whence would come the revenue necessary for upholding the dignity of sovereignty, for sustaining the military force, for maintaining all those in the royal service in some part or other of the public administration?» (ibid., p. 247).

Or, in other words, the presence of the court in Brazil would lead to a significant increase in economic activities, which would only be possible in a context of open trade. The irony of the situation lay precisely in the fact that such openness brought with it greater autonomy and political power for Brazil, thereby endangering the increasingly precarious equilibrium with the metropolis.

Another objection refuted by Silva Lisboa was the handing over to the British of the monopoly over Brazilian trade, in harmful competition with national traders. In fact, such a supposed negative consequence only derived from the greed of those who, accustomed to living under a monopoly situation, lost their privileges and guarantees. The author drew up a very vehement defence of the principle of competition as the way to satisfy individual interests, but also placed at the service of the nation, concluding that "those who wish for monopolies are always short-sighted and stumble over their own steps» (ibid., p. 259).

José da Silva Lisboa admits that difficult situations might occur momentarily for some traders and producers. However, generally speaking, he considers that the free importation of foreign goods (controlled only through the payment of the duties established in the Carta Régia) would represent a benefit and a stimulus to the development of economic activities, particularly in Brazil.

Silva Lisboa was not unaware of the arguments and objections insisting that the European metropolis, still trying to deal with the invasion, 
would necessarily be faced with an economic loss. However, his reply to this question was essentially political and pragmatic, expressed under the form of the reinvented doctrine of a new but impossible empire. It is worth paying close attention to his words, since they illustrate Silva Lisboa's return to the enlightened view of the empire defended by Rodrigo de Souza Coutinho:

"The sovereign's true interest is that the colonies should be closely linked to their government and common motherland, and that they should prosper as much as possible; for it is upon their close union and constant prosperity that the State depends for its greatest possible revenue and strength. Free trade does not tend to sacrifice the metropolis to the overseas dominions; instead it causes these integral parts of the monarchy to grow through their natural means of growth, and not some parts at the expense of the other parts.

Naturally, Brazil, by virtue of the benefit granted by His Royal Highness, must, with time, grow to a very high degree of opulence, population and prosperity, even more so if it has the good fortune of the court being established there; since, as the Holy Scriptures say, A king who sits on the throne of judgment winnows all evil with his eyes. So, the Portuguese Empire will be greatly respected in Europe, unconquerable in America, and extremely influential in the progress of civilisation» (ibid., pp. 268-269).

Between 1808 and 1810, Silva Lisboa was to publish other books and pamphlets extolling the merits of introducing legislation in favour of free trade and industry. His writing, always supported by an abundant rhetoric, is aimed at justifying and legitimising the decrees made by the Prince Regent and the government established in Rio de Janeiro, in order to create a space of greater economic openness in Brazil. His objective was to convince and persuade public opinion as to the appropriateness and good intentions of the measures, while at the same time establishing the doctrinal and theoretical framework that would afford them strategic coherence. In other words, Silva Lisboa did not only wish to applaud what was being done. He also sought to demonstrate the existence of universal principles and laws that would guide the public in the understanding that he builds up regarding the real significance of both the laws introduced and the actions taken by the government ${ }^{23}$.

${ }^{23}$ Silva Lisboa's endeavour in favour of economic development in Brazil was to be continued in the following years. His permanent commitment to change in Brazil made him one of the forerunners of political independence in 1822 . 


\section{CONCLUSION}

Political economy, as synthesised in Adam Smith's work, conveyed a series of prudent reflections on the nature of colonial trade and the need for its reform, ideas which had been gradually developing in different corners of Europe during the Enlightenment. Smith also clearly expressed the existence of disturbing doubts regarding the possibility of the maintenance of empires and their real or illusory wealth. As might be expected, many of the ensuing discussions concerning the prospects for colonies and empires show the influence of the arguments put forward in the Wealth of Nations. Portugal was no exception to this rule, particularly when the French threat compelled the Prince Regent, Dom João, and his court to escape to Brazil.

In the early writings of one of the most influential ministers of that time, Rodrigo de Souza Coutinho, it is possible to find several statements in favour of reforming and opening up the economic administration of the Brazilian territory, and even some comments defending the superiority of the principles of free competition. However, there is never any championing of the merits of complete freedom in international trade. Accepting this principle would have meant renouncing an autonomous development strategy and would have involved submitting the Portuguese economy to the distortions imposed by British economic potential.

However, after 1808, Rodrigo de Souza Coutinho was to become one of the most committed supporters of the free-trade principles of «sound political economy». Such a change of attitude was the result of a crucial strategic decision taken in a political and diplomatic situation in which the maintenance of political sovereignty implied making concessions and compromises in the economic field. The opening up of Brazilian ports and the signing of the Treaties of Commerce and Friendship in 1810 rewarded the British crown for its military help in freeing the metropolis which had been invaded by Napoleon's troops. In this particular context, Coutinho was able to justify his coherent pro-British stance and was led to accept the doctrinal presuppositions that dictated the new strategic guidelines for the development of the Portuguese economy. However, his adherence to the free-trade ideology can also be understood as the natural corollary of a process of doctrinal assimilation, which was certainly marked by his reading of Adam Smith's Wealth of Nations.

José da Silva Lisboa was also a prominent supporter of free trade and other liberal theses advanced in the Wealth of Nations. Obviously inspired by Smith's work, this prolific author may be regarded as the main PortugueseBrazilian activist working in support of the systematic adoption of liberal principles and aiming at a triumphant incursion of Smithian political economy into Brazilian territory. For Brazil seemed, after all, an ideal space for the implementation of the economic precepts of the new science of political economy. 
Thanks to the science of political economy, the foundations of the economic independence of Brazil began to be laid in 1808. The combination of the Napoleonic wars in Europe and the consequent transfer of the court to Brazil were the conditions that led to the inevitable opening up of the ports to trade and other forms of economic openness which dictated the end of the system of colonial monopoly. Yet the choices made at that time also found their legitimate justification in the enlightened universe of the prevailing economic doctrines.

1808-10 is not intended here to be considered as an early indication of the political independence of the Brazilian nation, which would only be achieved in 1822. However, when we look at the immediate implications of the events between 1808 and 1810, we cannot help but think that decisive steps were taken at the economic level for the construction of a particular form of citizenship, capable of dispensing with the traditional economic ties on which the old colonial pact was based, together with its concomitant system of mercantilist privileges.

From 1808 onwards, Portugal lost the colonial monopoly provided by Brazil and with it the safe guarantee of equilibrium or surplus in the balance of foreign trade, in which the goods re-exported from Brazil played a major role. It is therefore concluded that 1808 represented the foundation year of Brazil's economic autonomy and was a decisive step in the construction of its status as an independent nation.

\section{REFERENCES}

AleXANDRe, V. (1986): «Um momento crucial do subdesenvolvimento português: efeitos económicos da perda do império brasileiro». Ler História, 7, pp. 3-45.

- (1991): «Resposta à segunda nota crítica: Lains no país das adivinhas». Penélope, 5, pp. 165-178.

- (1993): Os Sentidos do Império. Questão Nacional e Questão Colonial na Crise do Antigo Regime Português, Porto: Edições Afrontamento.

Almodovar, A. (1993): «Introduction», in J. S. LisboA, Escritos Económicos Escolhidos (1804-1820), Lisboa: Banco de Portugal, vol. I, pp. ix-xxxii.

Arruda, J. A. (1980): O Brasil no Comércio Colonial, São Paulo: Hucitec.

- (2008): Uma Colónia Entre Dois Impérios. A Abertura dos Portos Brasileiros, 18001808, São Paulo: EDUSC.

Braun, C. R. (1989): La Cuestión Colonial y la Economia Clásica, Madrid: Alianza Editorial.

Caetano, A. C. (2008): A Economia Portuguesa no Tempo de Napoleão. Constantes e Linhas de Força, Lisboa: Tribuna da História.

CARdoso, J. L. (2001): «Nas malhas do império: a economia política e a política colonial de D. Rodrigo de Souza Coutinho", in J. L. Cardoso (ed.), A Economia Política e os Dilemas do Império Luso-Brasileiro (1790-1822), Lisboa: Comissão Nacional para as Comemorações dos Descobrimentos Portugueses, pp. 65-109.

- (2002): «O liberalismo económico na obra de José da Silva Lisboa». História Econômica e História de Empresas, 5 (1), pp. 147-164. 
[CLP] Colecção de Legislação Portuguesa desde a última compilação das Ordenações, 17501820, redigida pelo Desembargador António Delgado da Silva, Lisboa: Tipografia Maigrense, 1825-1830.

CoutinHo, R. S. (1977): Memória sobre o melhoramento dos domínios de Sua Majestade na América, in Coutinho (1993, vol. I, pp. 47-66).

- (1993): Textos Políticos, Económicos e Financeiros (1783-1811), Lisboa: Banco de Portugal, vols. I and II (edited by A. DinIz Silva).

Freitas, C. (1958): George Canning e o Brasil: Influência da Diplomacia Inglêsa na Formação Brasileira, São Paulo: Companhia Editora Nacional.

Hirschman, A. O. (1977): The Passions and the Interests. Political Arguments for Capitalism Before its Triumph, Princeton: Princeton University Press.

HonT, I. (2005): Jealousy of Trade. International Competition and the Nation-State in Historical Perspective, Cambridge MA and London: Harvard University Press.

LAINS, P. (1989): «Foi a perda do império um momento crucial do subdesenvolvimento português?». Penélope, 3, pp. 92-102.

- (1991): «Foi a perda do império um momento crucial do subdesenvolvimento português? - II». Penélope, 5, pp. 151-163.

Lima, O. (1909): Dom João VI no Brasil, 1808-1821, Rio de Janeiro: Livraria José Olympio.

LisboA, J. S. (1804): Princípios de Economia Política para Servir de Introdução à Tentativa Económica do Autor dos Princípios de Direito Mercantil, Lisboa: Impressão Régia. In Lisboa (1993, vol. I, pp. 1-121).

- (1808-1809): Observações sobre o comércio franco do Brasil, Rio de Janeiro: Impressão Régia. In Lisboa (1993, vol. I, pp. 185-320).

- (1993): Escritos Económicos Escolhidos (1804-1820), Lisboa: Banco de Portugal, vols. I and II (edited by A. ALmodovar).

Madureira, N. L. (1997): Mercado e Privilégios. A Indústria Portuguesa entre 1750 e 1834, Lisboa: Editorial Estampa.

Manchester, A. K. (1933): British Preeminence in Brazil, its Rise and Decline. A Study in European Expansion, Chapell Hill: The University of North Carolina Press.

MAXWELL, K. (1973): "The Generation of the 1790's and the idea of the Luso-Brazilian Empire», in D. ALden (ed.), The Colonial Roots of Modern Brazil, Berkeley: University of California Press, pp. 107-144.

- (1998): «Ideias imperiais», in F. Bethencourt and K. CHAudHuri (eds.), História da Expansão Portuguesa, Lisboa: Círculo de Leitores, vol. III, pp. 410-420.

Neves, G. P. (1995): «Do império luso-brasileiro ao império do Brasil, 1789-1822». Ler História, 27-28, pp. 75-102.

Novais, F. A. (1979): Portugal e Brasil na Crise do Antigo Sistema Colonial (1777-1808), São Paulo: Hucitec.

Oliveira, L. V., and Ricupero, R. (eds.) (2007): A Abertura dos Portos, São Paulo: Senac.

Paquette, G. B. (2008): Enlightenment, Governance and Reform in Spain and its Empire, 1759-1808, Basingstoke and New York: Palgrave MacMillan.

Pedreira, J. M. (1994): Estrutura Industrial e Mercado Colonial. Portugal e Brasil 17801830, Lisboa: Difel.

- (1998): "O fim do império luso-brasileiro», in F. Bethencourt and K. Chaudhuri (eds.), História da Expansão Portuguesa, Lisboa: Círculo de Leitores, vol. IV, pp. 215-227.

- (2000): «From growth to collapse: Portugal, Brazil and the breakdown of the old colonial system (1760-1830)». Hispanic American Historical Review, 80 (4), pp. 839-864. 
Pereira, M. H. (1987): «Atitudes políticas e relações económicas internacionais na primeira metade do século XIX em Portugal». Ler História, 10, pp. 53-73.

Rocha, A. P. (1996): A Economia Política na Sociedade Escravista, São Paulo: Editora Hucitec.

- (ed.) (2001): José da Silva Lisboa, Visconde de Cairu, São Paulo: Editora 34.

Schultz, K. (2001): Tropical Versailles: Empire, Monarchy, and the Portuguese Royal Court in Rio de Janeiro, 1808-1821, London and New York: Routledge.

SCHWARTZ, S. (1998): "O Brasil no sistema colonial», in F. BETHEncourt and K. Chaudhuri (eds.), História da Expansão Portuguesa, Lisboa: Círculo de Leitores, vol. III, pp. 138-153.

Semmel, B. (1970): The Rise of Free Trade Imperialism. Classical Political Economy, the Empire of Free Trade and Imperialism, 1750-1850, Cambridge: Cambridge University Press.

Silva, A. M.-D. (2002-2006): Portrait d'un Homme d'État: D. Rodrigo de Souza Coutinho, Comte de Linhares 1755-1812, Lisboa and Paris: Centre Culturel Calouste Gulbenkian, vol. I (Les années de formation, 1755-1796) and vol. II (L'homme d'État, 1796-1812).

Sмiтн, A. (1776): An Inquiry into the Nature and Causes of the Wealth of Nations (Glasgow Edition, Oxford: Oxford University Press, 1976).

STEVEns, D. (1975): «Adam Smith and the colonial disturbance», in A. SKINNER and T. Wilson (eds.), Essays on Adam Smith, Oxford: Clarendon Press, pp. 202-217.

Winch, D. (1965): Classical Political Economy and Colonies, London: LSE.

- (1996): "Adam Smith's "politique coloniale"». Cahiers d'Économie Politique, 27-28 (Actes du Colloque «Adam Smith et l'Économie Coloniale»), pp. 39-56. 